The Eastern Librarian, Volume 23(1), 2012, ISSN: 1021-3643 (Print). Pages: 74-90. Available Online: http://www.banglajol.info/index.php/EL

\title{
USE OF ELECTRONIC RESOURCES AND ITS IMPACT: A STUDY OF DHAKA UNIVERSITY LIBRARY USERS
}

\author{
Umme Habiba \\ Eastern University, Dhaka, Bangladesh \\ e-mail: habibaumme21@yahoo.com \\ Salma Chowdhury, $\mathrm{PhD}$ \\ Department of Information Science and Library Management \\ University of Dhaka, Dhaka-1000, Bangladesh
}

\begin{abstract}
This paper presents and analyses the status of electronic resources facilities and services provided by the Dhaka University Library (DUL). It also discusses the purpose of using e-resources, benefits, subject coverage status, overall user satisfactions, problems that are faced by DUL users while accessing e-resources and perceived impact of e-resources on users. Finally, it reports the results from questionnaire-based survey of e-resources use and its impact on DUL users.
\end{abstract}

\section{KEYWORDS}

Dhaka University Library, Electronic Resources, Electronic Services, Organization and Management of E-resources.

DOI: http://dx.doi.org/10.3329/el.v23i1.12122

\section{INTRODUCTION}

The library and information centre is a part of any educational institution, which is the hub of the teaching, and learning activities where students, teacher and researchers get their required information according to their need. In the traditional libraries users have to spend much more time for searching a small piece of information and for that they have to depend mainly on the library professionals or library staff. But in the age of information communication

74 The Eastern Librarian-peer-reviewed journal in LIS since 1965 
technology, computers are being used for day-to-day housekeeping activity of the library, which saves the time of the end users, and library professionals also and at the same time avoid duplication of work and make the library service smooth and effective (Sinha, 1990). Electronic resources are revolutioning in DUL. To provide better and faster user services in a convenient way, the DUL has decided to automate its operations and services. In 1998, the library started its automation program named as Dhaka University Automation Project (DULAP), Funded by UNDP and UGC (University of Grand Commission). From 2000, DUL started a new project for digitizing it. They have developed in-house software (temporary name Interim solutions). The DUL decided to convert some selective and rare materials from printed to electronic form by scanning. DUL provides a wide range of scholarly e-resources (about 35 publishers, 20,000 online journals), but for licensing reasons, most of them have to be restricted to members of the University of Dhaka. In this paper, an attempt has been made to show the existing situation of electronic resources in DUL, how DUL provide these electronic resources to the users, problems that are faced by DUL users while accessing electronic resources and the perceived impacts of electronic resources on their academic efficiency. Moreover, this paper also provides suggestions and recommendations to improve the electronic resources and services for the benefit of users.

\section{OBJECTIVES OF THE STUDY}

The study has been designed with a view to achieving the following objectives:

- Find out the present status of e-resources facilities and services provided by the DUL;

- Study the purpose and frequency of using the electronic resources available in the library;

- Locate the impediments faced by the users while accessing and using the e-resources in the library;

- Study the impact of electronic resources and services on the academic work of the users and

- Provide suitable suggestions and recommendations to improve the eresources and e-services for the benefit of users in DUL.

75 The Eastern Librarian-peer-reviewed journal in LIS since 1965 


\section{LITERATURE REVIEW}

There have been a number of studies that discussed the impact of e-resources use in the universities worldwide. Shuling (2007) analyzed the use of electronic resources in Shaanxi University of Science and Technology. The sample consists of 909 respondents of all types of library users. The study found that nearly 80 percent of respondents knew little about electronic resources. Nearly half the respondents use both printed and electronic resources, followed by print periodicals. Ray and Day (1998) on the other hand, conducted their study to determine the level of use of electronic resources and how students feel about various issues surrounding electronic resources. The findings of their study are that 91 per cent of respondents acknowledged access to a networked computer via university, and also that more internet access is from work place than from home. The most popular electronic resources used were CD-ROM and the internet. Only 37.5 per cent of the sample population used electronic journals as an information tool. Another study by Tenopir (2003), studied the 200 recent research publications that focus on the use of electronic library resources and were published between 1995 and 2003 in the report for the council on library and information resources. The study used a variety of research methods, including observations, surveys, interviews, experiments and transaction log analysis. The findings show that both faculty and students use and like electronic resources and most readily adopt them if the sources are perceived as convenient, relevant, and time saving to their natural work flow. Print medium is still used for some reading and is part of research in almost every discipline. Rao (1997) on the other hand, has discussed the impact of CD-ROM databases, internet and digital libraries on collection development. He has reported that it is quite significant. Finally, there is lack of research on electronic resources in Bangladesh. So, this study has been attempted discuss the electronic resources and its use in one of the premier universities in the country.

\section{METHODOLOGY}

A methodology used for collecting data was questionnaire based. All the questions were specifically prepared and closely related with the use of electronic resources and its impact. These questionnaires were randomly distributed to the DUL users and were successfully retrieved from users.

76 The Eastern Librarian-peer-reviewed journal in LIS since 1965 


\section{Sampling}

Category of User

A total of 120 questionnaires were distributed randomly to the DUL users, of which 100 were returned and used for analysis. Out of the 100 users, 10.0 percent are academics, 76.0 percent are students and 14.0 percent are researchers. Figure1shows user distributions of the respondents:

$\mathbf{N}=\mathbf{1 0 0}$

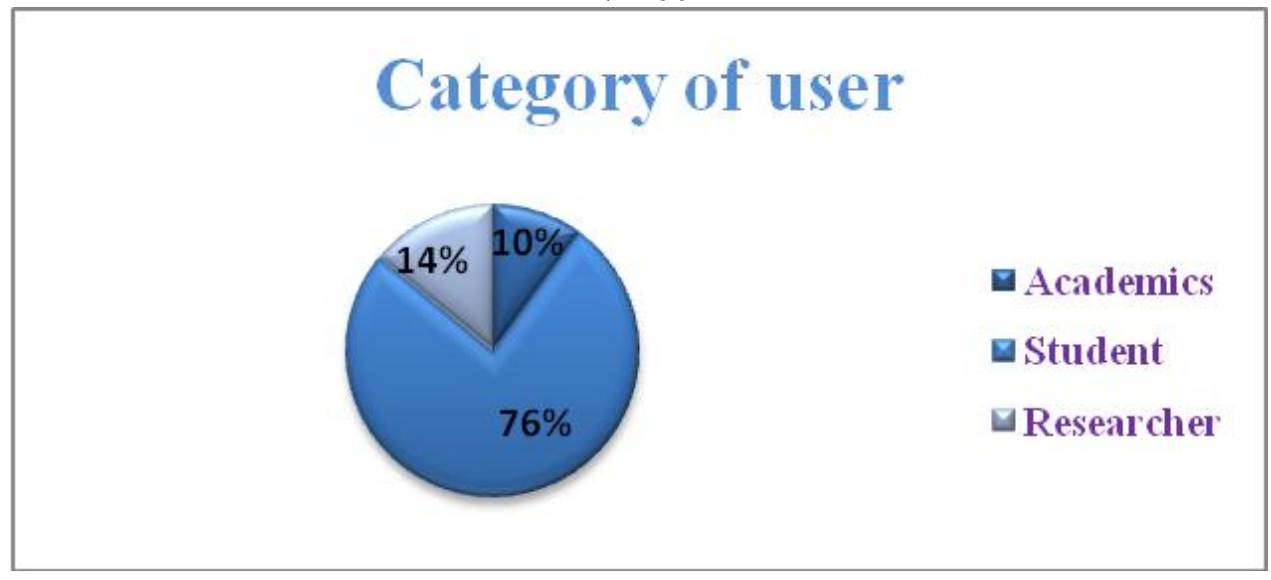

Figure 1: Category of user

\section{FINDINGS AND DISCUSSION}

\section{Electronic Resources Access and Use in DUL}

DUL provides online resources through contribution towards country subscription of online resources and other resources via PERI under the Bangladesh INASP-PERI consortium (BIPC) arrangement since 2007. The online journals are linked to the DUL web site (www.univdhaka.edu) and it provides very easy interface to its users. DUL provides its electronic resource services within our Dhaka University area. These services are open for all faculty members, students, researchers, officers and staffs of Dhaka University.

In 2008, DUL subscribe online journals through PERI and get over 35 publishers and over 7500 journals available which covers different subject contents. Those publishers' links are available to the DUL website. Those links

77 The Eastern Librarian-peer-reviewed journal in LIS since 1965 
helps users to access easily the desired journal articles. Every year, DUL includes new publishers through consortium.

Recently DUL get one more publisher named EBSCO. Now we can access EBSCO journal articles Journals from the following publishers are available via PERI programmed of INASP.

\section{Access to Internet}

The users were asked about access to internet. The findings showed that 3.0 percent users acknowledge access to internet at work place, 20.0 percent accessed internet at library, 30.0 percent accessed at home, 28.0 percent accessed internet at residential hall, and 19.0 percent users access at cyber café. Finally we can decide that, most of the users access internet at home and residential hall than other places. See Figure 2 below. It is also supports of the findings of Ray and Day (1998) they found that, 91\% of respondents acknowledged access to a networked computer via university and also that more internet access is from work place than from home.

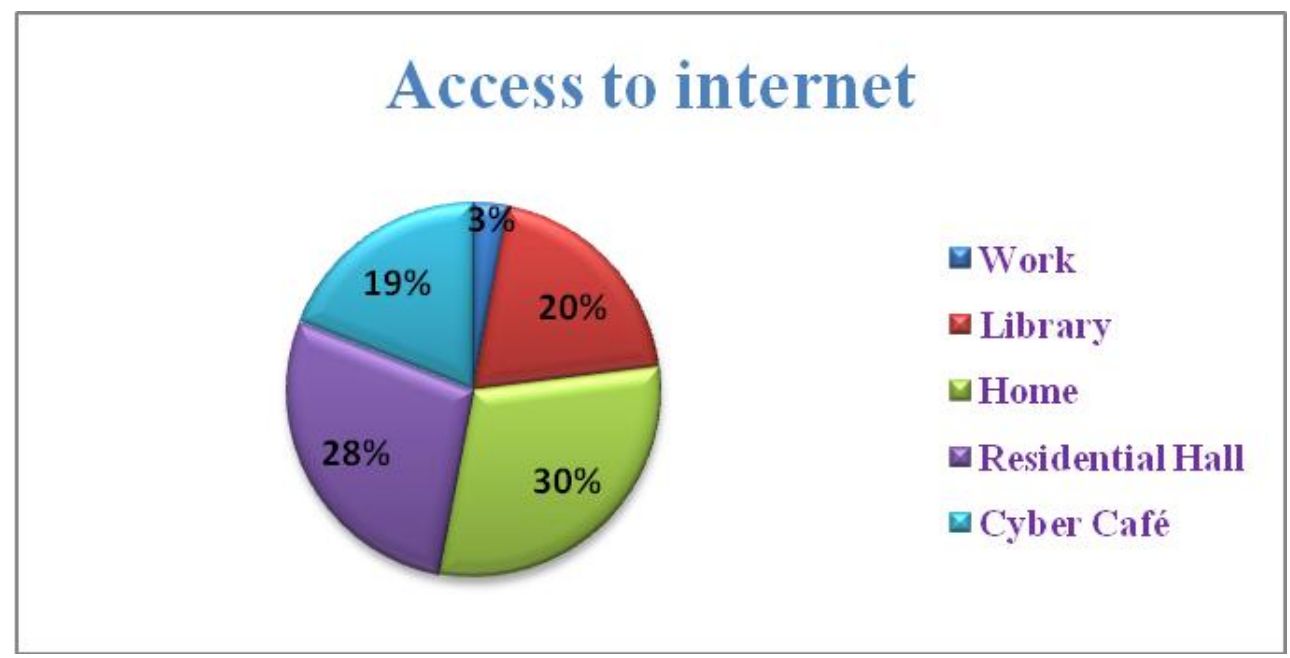

Figure 2: Access to internet

\section{Access to Electronic Resources}

From the returned questionnaires, it was found that most of the 44.0 percent users access to electronic resources every day, 27.0 percent accessed electronic resources a few times every week, 17.0 percent accessed at least once a week, 
3.0 percent accessed at least once a fortnight and 9.0 percent users accessed electronic resources at least once a month. Here we also see that, most of the DUL users used e-resources everyday, which is good sign for DUL. See Figure 3. Nicholas (2000) on the other hand found that, 58 percent of the student journalists used internet very frequently, 24 per cent sometimes, 15 percent occasionally and 3 percent never.

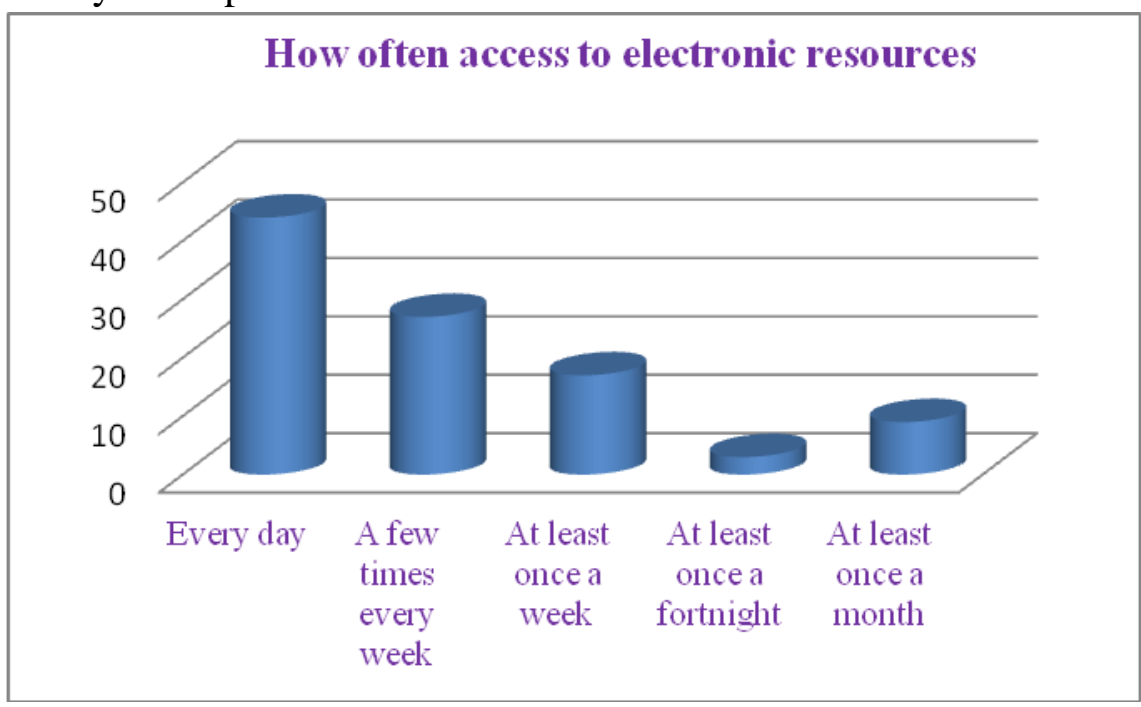

Figure 3: How often access to electronic resources.

\section{Look for Relevant Electronic Resources}

In response to this question, the users were asked about where they look for relevant electronic resources on the internet. The data about this question is shown below in Table 1.

Table 1: Look for Relevant Electronic Resources

\begin{tabular}{|l|c|c|c|c|}
\hline $\begin{array}{l}\text { Look for relevant electronic } \\
\text { resources }\end{array}$ & Academics & Student & Researcher & Percent \\
\hline University/library websites & 1 & 15 & 0 & 16.0 \\
\hline Subject guides/portals on the internet & 1 & 17 & 2 & 20.0 \\
\hline Web search engines & 5 & 39 & 8 & 52.0 \\
\hline online databases with links to full-text & 3 & 5 & 4 & 12.0 \\
\hline Total & 10 & 76 & 14 & 100.0 \\
\hline
\end{tabular}

79 The Eastern Librarian-peer-reviewed journal in LIS since 1965 
Table 1 reveals that, 16.0 percent users looking for relevant electronic resources by using University/Library websites, 20.0 users used subject guides/ portals on the internet for electronic resources, 52.0 percent mostly used web search engines to find relevant electronic resources on the internet and 12.0 percent used online database with links to full-text. So, from this study it is clear that half of the DUL users find their relevant e-resources with the use of web search engines.

\section{Purpose of Using Electronic Resources}

The DUL users use electronic resources for many purposes. According to the respondents, 54.0 percent users mostly used electronic resources for learning, 35.0 percent used e-resources for current information, 6.0 percent used electronic resources for research purpose and 5.0 percent used electronic resources for teaching purpose. See Figure 4. Here, it is found that, more than half of respondents used e-resources for learning purposes. Another study by Rehman and Ramzy (2004) investigated the awareness and use of electronic information resources among health academics. Results show that libraries are extensively used for research needs, preparation of lectures, and for obtaining current knowledge.

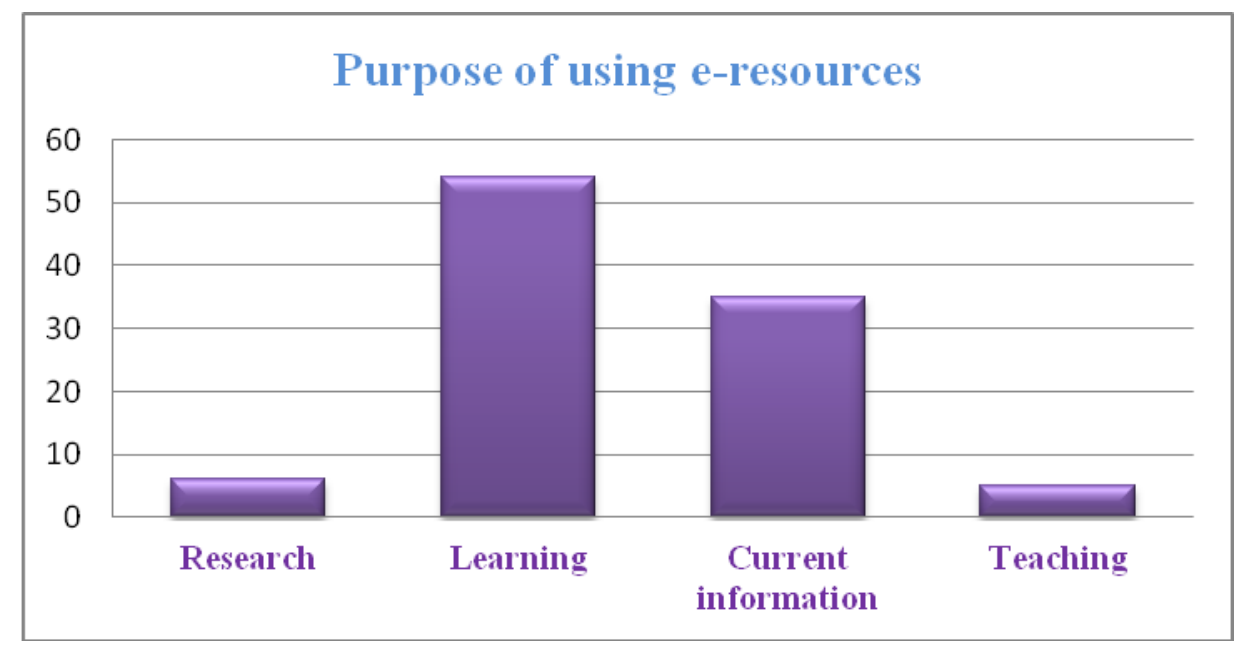

Figure 4: Purpose of using electronic resources 


\section{Types of Electronic Resources Use}

Analyzing the respondents replied, it has been found that, the majority of users 62.0 percent prefer to use electronic journals, second highest number of users 21.0 percent used electronic books, 11.0 percent users used library catalogue and the lowest 6.0 percent users used bibliographic databases. Here it is found that, most of the users use e-journals rather than library catalogue, bibliographic databases and e-books. See Figure 5.

The above data are represented by the following figure 5

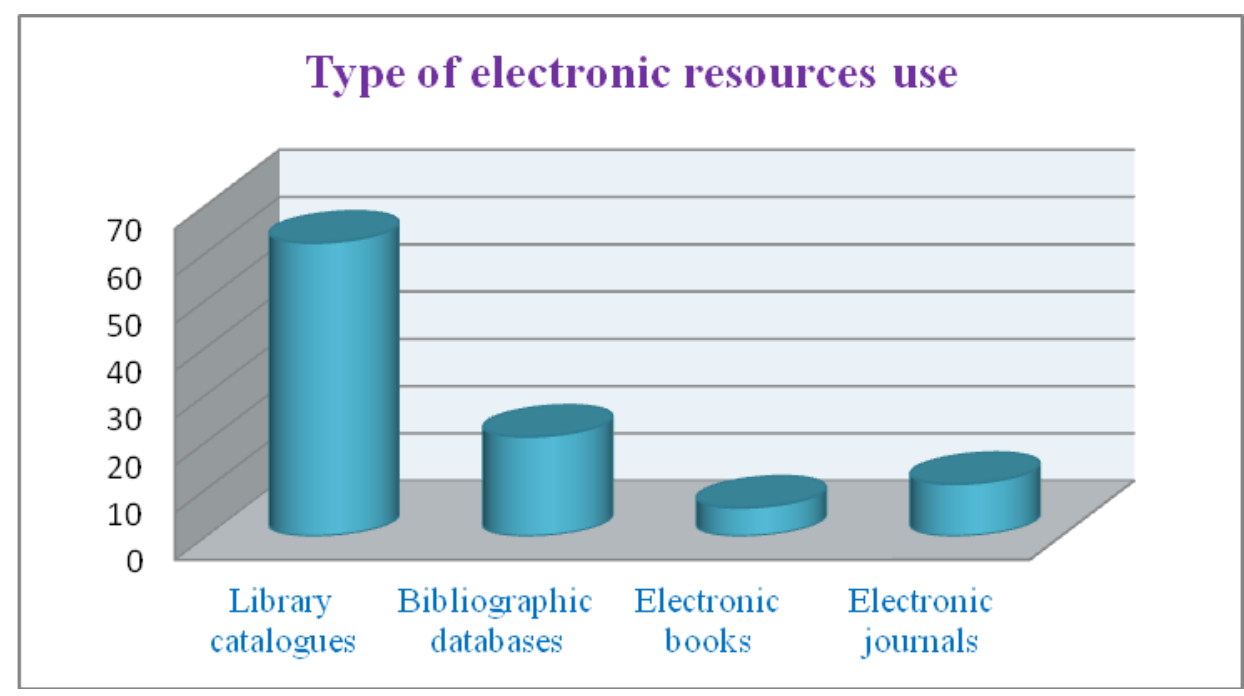

Figure 5: Type of electronic resources use

\section{Use Paid for Electronic Resources}

From the noticed of the respondents, it was found that, 52.0 percent users accessed electronic resources that are available free of charge, 13.0 percent accessed electronic resources that are provided by the University and 35.0 percent used pay themselves for electronic resources use. See Table 2.

Table 2: Use Paid for Electronic Resources

\begin{tabular}{|l|c|c|c|c|}
\hline paid for e-resources using & Academics & Student & Researcher & Percent \\
\hline No, I use only resources available free of charge & 4 & 39 & 9 & 52.0 \\
\hline
\end{tabular}




\begin{tabular}{|l|c|c|c|c|}
\hline Yes, the access is provided by the university & 4 & 7 & 2 & 13.0 \\
\hline Yes, I pay for the access to some resources myself. & 2 & 30 & 3 & 35.0 \\
\hline Total & 10 & 76 & 14 & 100.0 \\
\hline
\end{tabular}

\section{Features of Electronic Resources}

The DUL users were also asked for what features of electronic resources they considered to be the most important for the efficiency of their research/study. Analyzing the respondents reply, it was found that most of the users prefer to use electronic resources for up-to-date information than other features of electronic resources. According to the respondents, 56.0 percent users used eresources for up-to-date information, the second most 21.0 percent users considered to the most important features of electronic resources are for free availability, 12.0 percent used for quick retrievability, 10.0 percent used for full-text searching and 1.0 percent for link to other resources. See figure 6.

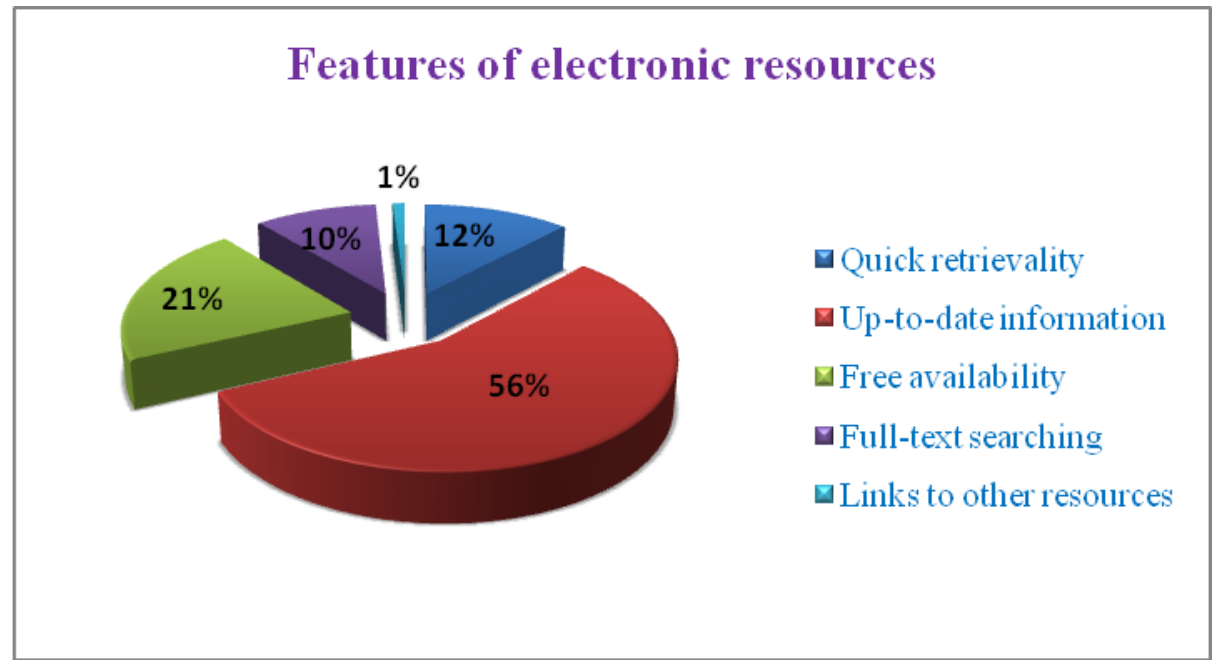

Figure 6: Features of electronic resources

Valuation of Electronic Resources and Services

\section{Evaluation of content}

\section{The Level of Materials Available}

From the findings, it shows that, out of the total respondents 11.0 percent users replied that the level of materials available in DUL is low, 20.0 percent users acknowledged that the level of materials are below average, 36.0 percents indicated their level as high, 11.0 percent used their level is very high and 2.0 
percent marked their level in case of materials availability as NA [Not applicable]. See Table 3.

Table 3: Level of Materials Available

\begin{tabular}{|l|c|c|c|c|}
\hline The level of materials available & Academics & Student & Researcher & Percent \\
\hline Low & 1 & 6 & 4 & 11.0 \\
\hline Below average & 2 & 17 & 1 & 20.0 \\
\hline Average & 5 & 27 & 4 & 36.0 \\
\hline High & 2 & 15 & 3 & 20.0 \\
\hline Very high & 0 & 9 & 2 & 11.0 \\
\hline NA & 0 & 2 & 0 & 2.0 \\
\hline Total & 10 & 76 & 14 & 100.0 \\
\hline
\end{tabular}

\section{The Coverage of the Subject/Work}

According to the filled in the questionnaires, it was found that 10.0 percent users replied that, the coverage of their subject/work is low, 28.0 percent respondents noticed electronic resources cover their subject/work in below average, 23.0 percent used level is an average, 31.0 percents explained that electronic resources cover their subject/work are highly, 6.0 percent used their level as very high and 2.0 percent used level as NA. See the Table 4.

Table 4: The Coverage of The Subject/Work

\begin{tabular}{|l|c|c|c|c|}
\hline \multicolumn{1}{|c|}{$\begin{array}{c}\text { The coverage of my } \\
\text { subject/work }\end{array}$} & Academics & Student & Researcher & Percent \\
\hline Low & 1 & 7 & 2 & 10.0 \\
\hline Below average & 3 & 21 & 4 & 28.0 \\
\hline Average & 5 & 15 & 3 & 23.0 \\
\hline High & 1 & 26 & 4 & 31.0 \\
\hline Very high & 0 & 5 & 1 & 6.0 \\
\hline NA & 0 & 2 & 0 & 2.0 \\
\hline Total & 10 & 76 & 14 & 100.0 \\
\hline
\end{tabular}

\section{Ease of Access}

From the findings it shows that 26.0 percent users replied that access to electronic resources are not easy, so they used their level of ease of access is low, 32.0 percent also replied ease of access to e-resources are below average, 24.0 percent users thought that access to electronic resources are easy and given their level as an average, 12.0 percent users responded that they can highly access e-resources, 5.0 percent also revealed their level of access as very highly 
and 1.0 percent user used NA for not applicable in this case. Table 5 explained the above data below:

Table 5: Ease of Access

\begin{tabular}{|l|c|c|c|c|}
\hline Ease of access & Academics & Student & Researcher & Percent \\
\hline Low & 1 & 19 & 6 & 26.0 \\
\hline Below average & 3 & 25 & 4 & 32.0 \\
\hline Average & 4 & 18 & 2 & 24.0 \\
\hline High & 2 & 9 & 1 & 12.0 \\
\hline Very high & 0 & 4 & 1 & 5.0 \\
\hline NA & 0 & 1 & 0 & 1.0 \\
\hline Total & 10 & 76 & 14 & 100.0 \\
\hline
\end{tabular}

Ease of Use

The findings reveals that, 31.0 percent users thought that they could not easily use electronic resources, so they used their level as low, 28.0 percent marked that ease of use in below average, 20.0 percent respondents revealed that the level of ease of use in an average, 16.0 percent users simultaneously replied that they can use electronic resources highly, 4.0 percent thought that the ease of access is very high and 1.0 percent marked their level as NA. See Table 6.

Table 6: Ease of Use

\begin{tabular}{|l|c|c|c|c|}
\hline Level of Ease of use & Academics & Student & Researcher & Percent \\
\hline Low & 1 & 24 & 6 & 31.0 \\
\hline Below average & 2 & 23 & 3 & 28.0 \\
\hline Average & 4 & 13 & 3 & 20.0 \\
\hline High & 3 & 11 & 2 & 16.0 \\
\hline Very high & 0 & 4 & 0 & 4.0 \\
\hline NA & 0 & 1 & 0 & 1.0 \\
\hline Total & 10 & 76 & 14 & 100.0 \\
\hline
\end{tabular}

\section{Technical Evaluation of Resources}

\section{Availability of computer facilities in the university}

From the analysis of these questionnaires it was found that, most of the user revealed that the computer facilities in DUL are not available, 43.0 percent users marked that the availability of computer facilities in DUL are low, 24.0 percent respondents also replied that the availability of computer facilities below average, 18.0 percent revealed their level as an average, 11.0 percent users also marked their level as high, 3.0 percent replied that the availability of 
computer facilities are very high and 1.0 percent used their level as NA. See Table 7 in below:

Table 7: Availability of Computer Facilities in the University

\begin{tabular}{|l|c|c|c|c|}
\hline $\begin{array}{l}\text { Level of availability of } \\
\text { computer facilities in the } \\
\text { university }\end{array}$ & Academics & Student & Researcher & Percent \\
\hline Low & 2 & 33 & 8 & 43.0 \\
\hline Below average & 3 & 18 & 3 & 24.0 \\
\hline Average & 1 & 14 & 3 & 18.0 \\
\hline High & 2 & 9 & 0 & 11.0 \\
\hline Very high & 2 & 1 & 0 & 3.0 \\
\hline NA & 0 & 1 & 0 & 1.0 \\
\hline Total & 10 & 76 & 14 & 100.0 \\
\hline
\end{tabular}

\section{Adequate Bandwidth to Access the Resources}

Table 8 shows that, bandwidth to access to electronic resources are not adequate in DUL, because 40.0 percent users revealed that the adequate bandwidth to access to electronic resources in below average, 23.0 percent marked the adequate bandwidth to access e-resources is low, but 25.0 percent replied that the bandwidth level of access to electronic resources in DUL is an average, 9.0 percent used their level in this case as high, 1.0 users thought that its level is very high and 2.0 percent used NA. Here we can decide that, the bandwidth is not adequate in DUL. See Table 8.

Table 8: Adequate Bandwidth to Access the Resources

\begin{tabular}{|l|c|c|c|c|}
\hline $\begin{array}{l}\text { Level of adequate bandwidth } \\
\text { to access the resources }\end{array}$ & Academics & Student & Researcher & Percent \\
\hline Low & 0 & 18 & 5 & 23.0 \\
\hline Below average & 5 & 30 & 5 & 40.0 \\
\hline Average & 3 & 19 & 3 & 25.0 \\
\hline High & 2 & 6 & 1 & 9.0 \\
\hline Very high & 0 & 1 & 0 & 1.0 \\
\hline NA & 0 & 2 & 0 & 2.0 \\
\hline Total & 10 & 76 & 14 & 100.0 \\
\hline
\end{tabular}

\section{Easy Navigation to Resources from Library Websites}

From the analysis it has been seemed that, easy navigation to resources from library websites are not good, because 16.0 percent users revealed that ease

85 The Eastern Librarian-peer-reviewed journal in LIS since 1965 
navigation of resources from DUL websites is low, 47.0 used their level in case of easy navigation in below average, simultaneously 26.0 percent used their level for easy navigation in an average, 9.0 percent respondents used their level as high and 2.0 percent used as very high in this case. So, overall easy navigation to resources in DUL is below average. Table 9 shows the following data below:

Table 9: Easy Navigation to Resources from Library Websites

\begin{tabular}{|l|c|c|c|c|}
\hline $\begin{array}{l}\text { Level of easy navigation to } \\
\text { resources from library websites }\end{array}$ & Academics & Student & Researcher & Percent \\
\hline Low & 1 & 14 & 1 & 16.0 \\
\hline Below average & 2 & 35 & 10 & 47.0 \\
\hline Average & 6 & 18 & 2 & 26.0 \\
\hline High & 1 & 7 & 1 & 9.0 \\
\hline Very high & 0 & 2 & 0 & 2.0 \\
\hline Total & 10 & 76 & 14 & 100.0 \\
\hline
\end{tabular}

\section{Overall User Satisfaction}

From the analysis of the questionnaires, it was found that, the overall user satisfaction levels of e-resources are varying from user to user. It means that 5.0 percent users are not satisfied with the above factors such as, evaluation of content, technical evaluations of resources, 19.0 percent respondents marked their satisfaction level in below average, but 58.0 percent replied that, in an average they are satisfied with the above factors, 17.0 percent used their satisfaction status as high and 1.0 percent used as very high. So, it was found that more than half of the users are generally satisfied with the e-resources use. See Table 10.

Table 10: Overall User Satisfaction

\begin{tabular}{|l|c|c|c|c|}
\hline Level of overall user satisfaction & Academics & Student & Researcher & Percent \\
\hline Low & 1 & 3 & 1 & 5.0 \\
\hline Below average & 0 & 15 & 4 & 19.0 \\
\hline Average & 7 & 46 & 5 & 58.0 \\
\hline High & 2 & 12 & 3 & 17.0 \\
\hline Very high & 0 & 0 & 1 & 1.0 \\
\hline Total & 10 & 76 & 14 & 100.0 \\
\hline
\end{tabular}




\section{Problems of Using Electronic Resources}

According to the filled in the questionnaires, here found some problems that are faced by the users when they are using e-resources. It means, 20.0 percent users acknowledge only a limited number of titles available, 10.0 percent indicated limited access to back issues, 14.0 percent faced difficulty in finding relevant information, 7.0 percent indicated e-resources of DUL cannot be accessed from home, 30.0 percent users given their opinion on limited access to computers and 19.0 percent indicated slow download speed. See Figure 7.

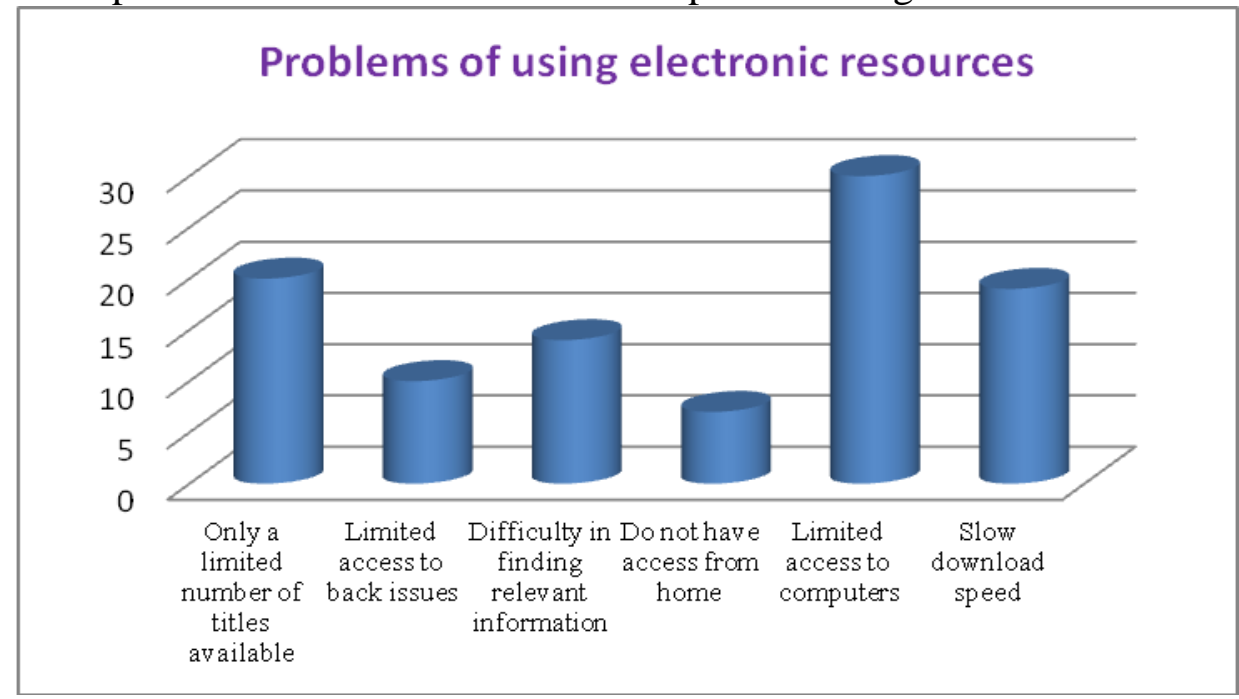

Figure 7: Problems of using electronic resources

\section{Level of Success in Research/Academic Work}

Analyzing the respondents replied, it was found that most of the DUL users used electronic resources for their research/academic work. According to the respondents, 55.0 percent users given level of success for using electronic resources as an average, 20.0 percent indicated their success level is high, 5.0 percent used as very high, 9.0 percent explained their success level for using electronic resources is low and 6.0 percent used level as very low. So, it is clear that users are successful in their research/academic work by using DUL eresources. The above data are showing below in Figure 8. 


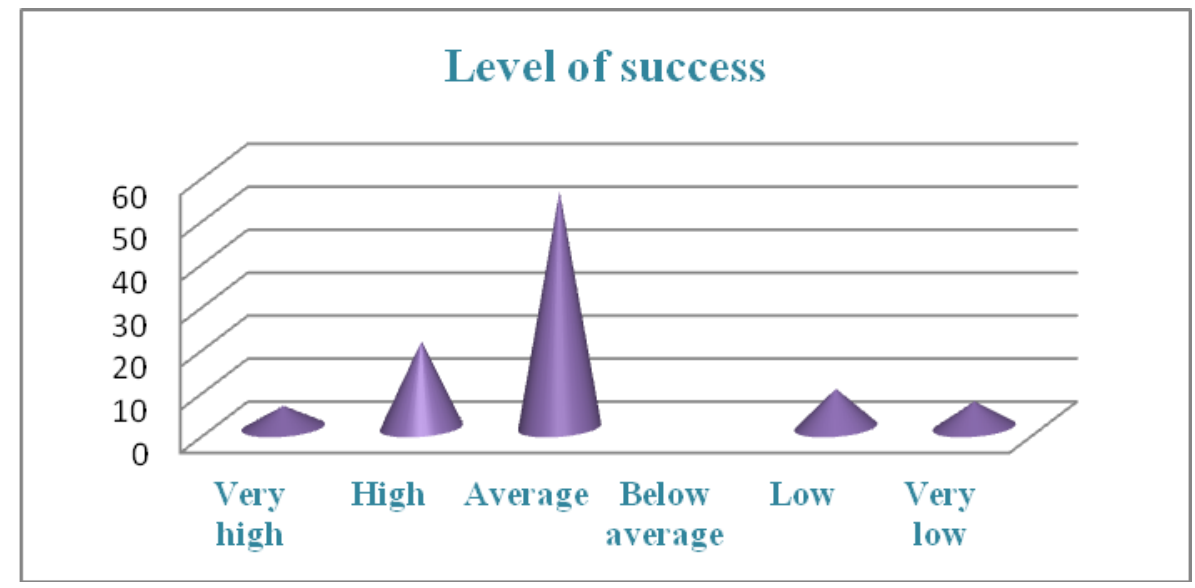

\section{Benefits of E-Resources}

Figure 8: Level of success.

Findings showed that, 26.0 percent users benefited from electronic resources as excellent, 37.0 percent users marked using electronic resources as average, 10.0 percent given their benefit level as poor and 27.0 percent as good. The benefits of e-resources are showing below by the following Figure 9 .

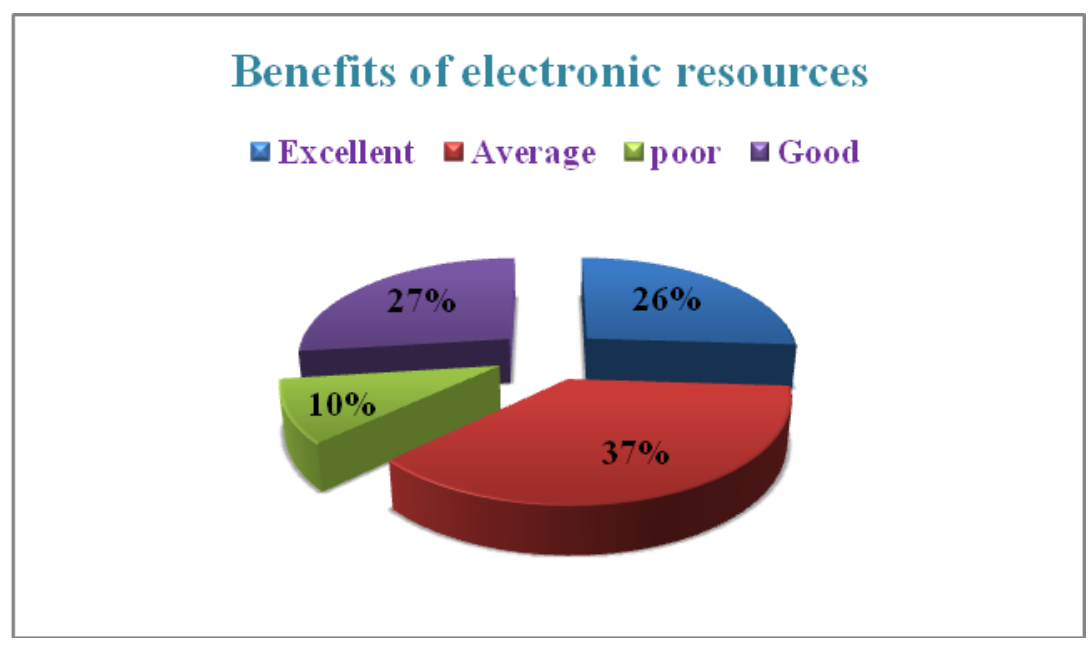

Figure 9: Benefits of electronic resources

\section{CONCLUSION AND RECOMMENDATIONS}

This paper confirms that a large number of e-resources are made available in DUL. This study reveals that, a majority of the users of DUL use e-resources for their learning purpose. It was found that, e-resources materials in DUL are 
available and users are generally satisfied with these materials. Although DUL lacks of infrastructure facilities, the existing e-resources can fulfill user needs. Moreover, DUL should arranges more training programmes for users, appoint trained professionals with ICT skills and accommodated users opinions on subscribing new e-journals. With the growing popularity of e-resources, the following recommendations are made for improvement in the use of eresources in DUL:

- Development of infrastructure facilities for accessing electronic resources by the users and to cover all the subjects content of Dhaka University, the library should subscribe more e-journals;

- DUL should increase the budget for subscribing more electronic resources. Without adequate budget library cannot cover all subjects' content. The e-journal cost is increasing day by day and among those the current issues are more costly than back issues. Most of the researchers and faculty member's requirements are current issues of article; some of them told that they no need to see the back issues of ejournals;

- Before and after the electronic resources subscription, survey on users should be done at regular interval. Library should also receive information and suggestions from the faculty members and the students, which need to subscribe or not;

- DUL should organize training program for the faulty members and the students so that they can know about different search interface, latest changes of the journals site and develop sophisticated searching and retrieval skills or techniques;

- Bandwidth of internet connection must be increased in DU campus. Faster internet access should be offered to minimize download time.

\section{REFERENCES}

Ali, Naushad (2005). The use of electronic resources at IIT Delhi Library: a study of search behaviors. The Electronic Library, 23(6), 691-700.

Crawford, J. C. \& Daye, A. (2000). A survey of the use of electronic services at Glasgow Caledonia University Library. The Electronic library, 18(4), 255-265.

Dadzie, Perpetua S. (2005). Electronic resources: access and usage at Ashesi University College, campus-wide information systems, 22(5), 290-297.

89 The Eastern Librarian-peer-reviewed journal in LIS since 1965 
Edwards, C.E., Day J.M. \& Walton, G. (1995). IMPACT project: the impact on people of electronic libraries. Aslib Proceedings, 47(9), 203-208.

Herring, Susan D. (2002). Use of electronic resources in scholarly electronic journals: a citation analysis. College and Research Libraries, 63(4) 334-340.

Ibrahim, Ahmed E. (2004). Use and user perception of electronic resources in the United Arab Emirates University (UAEU). Libri, 54(1), 18-29.

Kelly, Kimberly B. \& Gloria J. (2003). Trends in distant student use of electronic resources: a survey. College and Research Libraries, 64(3), 176-190.

Kumar, Arun, (2009). Use and usage of electronic resources in Business Schools in India: FIIB. International Conference on Academic Libraries, 46, 573-578.

Miller, R.H. (2000). Electronic resources and academic libraries, 1980-2000: a historical perspective. Library Trends, 48(4), 645-670.

Monopli, M., Nicholas, D., Georgiou, P. \& Korfiati, M. (2002). A user oriented evaluation of digital libraries: a case study 'the electronic journals' services of the library and information service of the University of Petra, Greece. Aslib Proceedings, 54(2), 103-117.

Rao, Y. Srinivasa \& Choudhury, B.K. (2009). Availability of electronic resources at NIT libraries in India: a study. International Conference on Academic Libraries, 630-635. Retrieved from http://crl.du.ac.in/ical09/papers/index_files/ical106_68_169_2_RV.pdf

Ray, K. \& Day, J. (1998). Student attitudes towards electronic information resources. Information Research, 4(2), 1-32.

Rogers, S. A. (2001). Electronic journal usage at Ohio State University. College and Research Libraries, 62(1), 25-34.

Sadia, H. (2011). The use and impact of electronic resources at the University of Lagos. Library Philosophy and Practice, 472. Retrieved from http://digitalcommons.unl.edu/cgi/viewcontent.cgi?article=1490\&context=libphil prac

Smith, Erin T. (2003). Changes in faculty reading behaviors: the impact of electronic journals on the University of Georgia. The Journal of Academic Librarianship, 29(3), 162-168.

Tenopir, Carol (2003). Use and users of electronic library resources: an overview and analysis of recent research studies. Council on Library and Information Resources, 8(3), 1-66.

University of Dhaka. (2008-2009). Annual report of the University of Dhaka.

Waldman, Micacla (2003). Freshmen's use of library electronic resources and selfefficacy. Information Research, 8(2), 23-25.

90 The Eastern Librarian-peer-reviewed journal in LIS since 1965 